\title{
The Influence of Personal and Professional Commitments on Digitally Disconnected Experiences
}

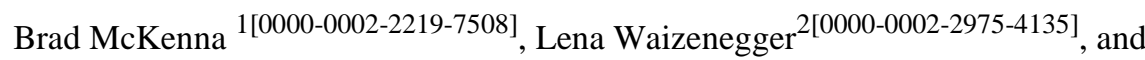 \\ Wenjie Cai ${ }^{3[0000-0002-1505-7240]}$ \\ ${ }^{1}$ University of East Anglia, Norwich, United Kingdom \\ b.mckenna@uea.ac.uk \\ 2 Auckland University of Technology, Auckland, New Zealand \\ lena.waizeneggereaut.ac.nz \\ ${ }^{3}$ University of Greenwich, London, United Kingdom \\ w.caiegreenwich.ac.uk
}

\begin{abstract}
In our ubiquitously connected world, it becomes more and more difficult to disconnect and leave all personal and professional commitments behind while on holiday. Mobile technology allows us to be connected wherever and whenever we want, but at the same time shifts expectations towards constant availability and responsiveness among friends and colleagues. Applying a qualitative research approach, we explored how social and professional commitments influence decisions and experiences of travelers that go on a digital-free holiday. Using the theoretical lens of surveillance, we found that travelers are digitally surveilled not only by their friends and family members on social media, but also by their superiors and colleagues through email and social networks. The expectations of being constantly available and responsive extend into their holiday, which makes it difficult for travelers to truly disconnect and enjoy their digital free travel experience. At the same time, they are inclined to engage in social surveillance of their peers which creates the constant urge to learn about any updates from their private and professional networks. We contribute to the tourism and information systems literature, by explaining how private and professional commitment influence the digital-free travel experience and extend the concept of surveillance to the work context.
\end{abstract}

Keywords: Digital-free travel, Surveillance, Private and Professional Commitments, Mobile Technologies

\section{Introduction}

Ubiquitous connectivity has resulted in blurred boundaries of home/away and leisure/work [1, 2]. While technology offers various conveniences to travelers, it becomes increasingly difficult for them to switch off during their holidays due to increasing expectations of constant availability and responsiveness [3-5]. The idea of reviving digital disconnections and escapism on holiday has been popular recently in both travel products and academic studies [6]. In the past few years, tourism organizations including VisitEngland and VisitScotland have highlighted the trend of digital detox and emphasized the strong connection between wellness tourism and efficient use of smartphones. The idea of going off-grid on holiday is popular among those who are highly connected in their daily lives. 
However, although these travelers are motivated to disconnect, the expectations from their work and social environment regarding the traveler's online availability and responsiveness affect their freedom to switch off. In this paper, we explore the personal and professional commitments which impact the experiences of digital-free travel using the concepts of interpersonal electronic surveillance (IES) [7] and social surveillance [8, 9]. IES results in the surveillance of individuals using digital technologies, while social surveillance can be understood as using web 2.0 sites such as social media to keep track of the activities of friends, family and acquaintances [9]. The goal of this paper is to show that surveillance does not only take place in a private but also professional context through email response tracking or response behavior on enterprise social networks, for example, Slack.

Technology is integrated into many aspects of a holiday, from making bookings, navigation, searching for information, and maintaining connections back home. However, these technologies have also become tools of surveillance [10]; of monitoring [11]; and of constant interruptions [12] which can blur the boundaries of 'home' and 'away'. Despite the growing desire for digital-free travel [6, 13], these issues of surveillance, monitoring, and interruptions can place a barrier to disconnecting, or have a negative impact on the digital-free holiday experience. Therefore, using the concepts of surveillance, the research question in this paper is: how do social and professional commitments influence decisions and experiences of digital-free travel?

The paper presents a research in progress paper and is structured as follows. First, we present a literature review on surveillance and digital-free travel. Following this, we present our methods section. Next, we present some of our preliminary findings, and conclude the paper.

\section{Literature Review}

Mobile technology is reconfiguring time and space, social relations, and enables tourists to be socially present while physically absent [14]. This idea of 'absent presence' [15] has been investigated as the notion of 'copresence' in the tourism literature [16]. However, copresence could lead to negative effects such as lack of social interactions, fewer experiences of others, or decreased well-being [3].

In the past, travel was largely associated with 'away' and 'escapism' from mundane everyday life, both physically and socially. The involvement of mobile technology detaches physical and social proximity, and enables a person's mediated presence [17] when he/she is on holiday. The copresence of tourists thus brings their daily lives on holiday by constantly engaging with their personal and professional commitments mediated by advanced mobile technology [18].

\subsection{Surveillance}

Mobile devices and social media are common tools for sharing location and other personal information with friends and other users of digital services [19], however these technologies are also a means of surveillance to see what friends, family, and acquaintances are doing [7] and have become accepted as the norm in our daily lives [8]. IES relates to the digital strategies that individuals use to follow other users online and offline behavior. IES is a goal-orientated behavior which includes the surveillance of family members, friends, romantic partners, or colleagues. IES can occur through digital technologies such as social media, bulletin boards, personal websites, blogs [7], and mobile devices [19]. More specifically, IES results in social surveillance which arises from the continual investigations of others' digital traces left by people as they live in their highly connected lives [9]. People are aware of this constant monitoring and tailor their social media content with an audience in mind [20]. Marwick [9] distinguishes social surveillance from other forms of surveillance 
with three parameters: power, hierarchy, and reciprocity and argues that the desire to share content means they want to be seen by others.

The concept of surveillance as a form of interpersonal and social relations has been discussed by Germann Molz [21] in a tourism context. With the normalization of copresence, many travelers do not only share their travel experience constantly online; they are even expected to be virtually available and visible to audiences' surveilling gaze. Some travelers are expected to provide updates to appease worried relatives and friends. The updates allow parents, friends and co-workers to surveille the traveler and check where they are, what they are doing and if they are safe. The pressure to update the people that stayed at home e.g. parents, friends and co-workers creates pressure that to some extent limits their freedom of travelling. Due to mobile technologies travelers can always be contacted by email, social media or instant messengers; therefore, they can never hide or escape from this implied surveillance. Germann Molz [21] suggests the expectation of visibility and availability by audiences through online social networks may exacerbate rather than appease. Travelers oftentimes let their web audience know through out of office email replies or instant messaging that they might lose signal or the Internet connection when they stay in technological black holes (i.e. no phone signal) or consciously switch off their phones [23]. Nevertheless, parents, friends or colleagues start worrying about them or are annoyed as they are waiting for important information after only a few quiet days. These collective expectations concerning availability and responsiveness have been explored by Mazmanian, Orlikowski, and Yates [4] in the workplace context. They found that the increasing expectations towards availability and responsiveness led to the spiral of escalating engagement and diminished the employees' autonomy. This made it difficult for them to disconnect from work and led to increased stress levels and work-life conflict. Despite research on organizational studies focusing on the concept of disconnection from work, there has been sparse focus in tourism research.

\subsection{Digital-Free Travel}

Research has shown that digital-free travel lead to various positive outcomes such as improved well-being and work-life balance [e.g. 23, 24]. However, according to Dickinson et al. [23] some tourists cannot embrace the idea of disconnection due to the perceived negative emotions or experiences. People who are self-motivated to engage in digital-free tourism, experience professional and personal commitments that make them feel oppressed and they cannot escape the constant surveillance [25].

Much of the disconnection literature focused on negative emotions such as anxiety and tensions [26], and the idea of being off-the-grid creates anxious and distressing feelings for some people [27]. Some studies have focused on the emotional effects of being disconnected, e.g. Paris et al. [26] researched anxieties and social tensions. Tanti and Buhalis [28] explored five consequences (availability, communication, information obtainability, time consumption, and supporting experiences) of being (dis)connected. However, these studies did not explore personal and professional commitments, as well as the pressure of copresence as key triggers of these negative emotions.

Germann Molz and Paris [29], Paris et al. [26], and Neuhofer and Ladkin [30] suggested that there are lack of empirical studies on digital-free travel with few exceptions [e.g. 26, 31]. Most studies reported findings of disconnection only as a secondary finding by asking participants to recall their 'connected' experiences. For example, Rosenberg [32] explored the disconnection topic by surveying backpackers about their connected behavior. There has been research on tourists who were forced to disconnect due to a 'technology dead zone', an area with no or poor connection [31], and recently, e-lienation [33], and media discourse of digital-free travel [24] providing essential insights into this topic. 


\section{Methodology}

This study is underpinned by the interpretive paradigm using the diary method and semi-structured interviews [34, 35], and builds on the prior work of the authors (references suppressed for blind review). In tourism studies, the diary method has been adopted to understand travel behavior and experiences [36]. Participants were recruited through a combination of self-selection and snowballing sampling techniques. The project was marketed with a public post on Facebook with the request for interested people to contact us. Further selection criteria were applied to ensure participants are frequent digital technology users and desired to take part in digitalfree travel experiences. In the participant information sheet, we operationalize our definitions of disconnection and technology as: mobile, computer, laptop, tablet, Internet, social media, sat navigator, television, or radio/audio player.

The data collection was conducted in two stages. In the first stage, participants were instructed with guidelines to write diaries to record their instant emotions and detailed accounts before, during and after their disconnected experiences. In addition, we also asked participants to note down occasions where they had to finish the digital-free experience before their initial plan. This stage was conducted between August 2016 and March 2017. The richness of the diary data recorded several interesting narratives worth further investigation. In the second stage between April and October 2017 we conducted semi-structured in-depth interviews to further investigate participants' reflections of their disconnected experiences. Most of the interviews were conducted face-to-face, only one took place over the phone.

In total, 24 participants (14 male and 10 female) from 7 countries traveled to 17 countries and regions. Participants are mostly millennials except for two that belong to Generation X. 15 diaries were hand-written by participants and transcribed by them after their trips. In addition, we conducted 18 interviews. We analyzed our data following the guidelines of thematic analysis [37] to identify the key concepts in our data. Table 1 contains our participant information. All participants are working professionals.

Table 1. Participant information (S: Sex; DD: Disconnect Duration; D: Diary; I: Interview)

\begin{tabular}{|l|l|l|l|l|l|l|l|l|}
\hline Name & S & Age & Travel From & Travel To & $\begin{array}{l}\text { Total } \\
\text { Trip }\end{array}$ & DD & D & I \\
\hline James & M & $\begin{array}{l}35- \\
40\end{array}$ & Norwich, UK & Ely, UK & 1 & 1 & X & \\
\hline Thomas & M & $\begin{array}{l}25- \\
30\end{array}$ & Norwich, UK & Ely, UK & 1 & 1 & X & \\
\hline & M & $50+$ & $\begin{array}{l}\text { Manchester, } \\
\text { UK }\end{array}$ & $\begin{array}{l}\text { Hebrides, } \\
\text { UK }\end{array}$ & 13 & 7 & X & \\
\hline John & Morwich, UK & $\begin{array}{l}\text { Vienna, } \\
\text { Austria }\end{array}$ & 4 & 3 & X & \\
\hline Richard & M & $\begin{array}{l}35- \\
40\end{array}$ & $\begin{array}{l}\text { Arlington, } \\
\text { Virginia, USA }\end{array}$ & $\begin{array}{l}\text { Orleans, } \\
\text { Massachuset } \\
\text { ts, USA }\end{array}$ & 6 & 1 & X & \\
\hline
\end{tabular}




\begin{tabular}{|c|c|c|c|c|c|c|c|c|}
\hline Frank & $\mathrm{M}$ & $\begin{array}{l}40- \\
45\end{array}$ & $\begin{array}{l}\text { Arlington, } \\
\text { Virginia, USA }\end{array}$ & $\begin{array}{l}\text { Orleans, } \\
\text { Massachuset } \\
\text { ts, USA }\end{array}$ & 6 & 1 & $X$ & $\mathrm{X}$ \\
\hline Youngqi & $\mathrm{F}$ & $\begin{array}{l}30- \\
35\end{array}$ & $\begin{array}{l}\text { Xiamen, } \\
\text { China }\end{array}$ & $\begin{array}{l}\text { Neuschwans } \\
\text { tein, } \\
\text { Germany }\end{array}$ & 10 & 2 & $X$ & $\mathrm{X}$ \\
\hline $\begin{array}{l}\text { Zhenpen } \\
\text { g }\end{array}$ & $\mathrm{M}$ & $\begin{array}{l}25- \\
30\end{array}$ & $\begin{array}{l}\text { Guangzhou } \\
\text { China }\end{array}$ & $\begin{array}{l}\text { Macau, } \\
\text { China }\end{array}$ & 2 & 0.5 & & $\mathrm{X}$ \\
\hline \multirow[t]{2}{*}{ Billy } & $\mathrm{M}$ & $\begin{array}{l}20- \\
25\end{array}$ & $\begin{array}{l}\text { Melbourne, } \\
\text { Australia }\end{array}$ & $\begin{array}{l}\text { Switzerland } \\
\text { and France }\end{array}$ & 3 & 1 & $\mathrm{X}$ & $\mathrm{X}$ \\
\hline & & & $\begin{array}{l}\text { Melbourne, } \\
\text { Australia }\end{array}$ & $\begin{array}{l}\text { Berlin, } \\
\text { Germany }\end{array}$ & 3 & 1 & $\mathrm{X}$ & $\mathrm{X}$ \\
\hline Anita & $\mathrm{F}$ & $\begin{array}{l}25- \\
30\end{array}$ & $\begin{array}{l}\text { Edinburgh, } \\
\text { UK }\end{array}$ & $\begin{array}{l}\text { Cerveny } \\
\text { Klastor, } \\
\text { Slovakia }\end{array}$ & 1.5 & 1.5 & $\mathrm{X}$ & \\
\hline Sally & $\mathrm{F}$ & $\begin{array}{l}30- \\
35\end{array}$ & Auckland, NZ & $\begin{array}{l}\text { Queenstown, } \\
\text { NZ }\end{array}$ & 3 & 1 & $X$ & $\mathrm{X}$ \\
\hline Jiaying & $\mathrm{F}$ & $\begin{array}{l}35- \\
40\end{array}$ & $\begin{array}{l}\text { Portsmouth, } \\
\text { UK }\end{array}$ & $\begin{array}{l}\text { Copenhagen, } \\
\text { Denmark }\end{array}$ & 3 & 2 & $\mathrm{X}$ & $\mathrm{X}$ \\
\hline Lisa & $\mathrm{F}$ & $\begin{array}{l}25- \\
30\end{array}$ & $\begin{array}{l}\text { Munich, } \\
\text { Germany }\end{array}$ & $\begin{array}{l}\text { Taipei, } \\
\text { Taiwan }\end{array}$ & 3 & 3 & $\mathrm{X}$ & \\
\hline Heike & $\mathrm{F}$ & $\begin{array}{l}25- \\
30\end{array}$ & $\begin{array}{l}\text { Innsbruck, } \\
\text { Austria }\end{array}$ & Cuba & 13 & 13 & & $\mathrm{X}$ \\
\hline Susan & $\mathrm{F}$ & $\begin{array}{l}30- \\
35\end{array}$ & Auckland, NZ & Tonga & 5 & 5 & & $\mathrm{X}$ \\
\hline Sean & $\mathrm{M}$ & $\begin{array}{l}30- \\
35\end{array}$ & Auckland, NZ & Tonga & 5 & 5 & & X \\
\hline Stephan & $\mathrm{M}$ & $\begin{array}{l}25- \\
30\end{array}$ & $\begin{array}{l}\text { Innsbruck, } \\
\text { Austria }\end{array}$ & Cuba & 13 & 13 & & $\mathrm{X}$ \\
\hline Rory & $\mathrm{F}$ & $\begin{array}{l}30- \\
35\end{array}$ & Auckland, NZ & $\begin{array}{l}\text { Abel } \\
\text { Tasman } \\
\text { National } \\
\text { Park, NZ }\end{array}$ & 4 & 3 & & $\mathrm{X}$ \\
\hline Nico & $\mathrm{M}$ & $\begin{array}{l}30- \\
35\end{array}$ & Auckland, NZ & $\begin{array}{l}\text { Abel } \\
\text { Tasman } \\
\text { National } \\
\text { Park, NZ }\end{array}$ & 4 & 3 & & $\mathrm{X}$ \\
\hline Doug & $\mathrm{M}$ & $\begin{array}{l}30- \\
35\end{array}$ & Auckland, NZ & $\begin{array}{l}\text { Abel } \\
\text { Tasman } \\
\text { National } \\
\text { Park, NZ }\end{array}$ & 4 & 3 & & $\mathrm{X}$ \\
\hline Steven & $\mathrm{M}$ & $\begin{array}{l}30- \\
35\end{array}$ & Auckland, NZ & Cook Islands & 7 & 7 & & $\mathrm{X}$ \\
\hline Larissa & $\mathrm{F}$ & $\begin{array}{l}25- \\
30\end{array}$ & $\begin{array}{l}\text { Innsbruck, } \\
\text { Austria }\end{array}$ & $\begin{array}{l}\text { Kiev, } \\
\text { Ukraine }\end{array}$ & 14 & 0 & & $\mathrm{X}$ \\
\hline
\end{tabular}




\begin{tabular}{|l|l|l|l|l|l|l|l|l|}
\hline Lauren & F & $\begin{array}{l}25- \\
30\end{array}$ & Auckland, NZ & Fiji & 14 & $3-4$ & & X \\
\hline Noah & M & $\begin{array}{l}25- \\
30\end{array}$ & Auckland, NZ & Fiji & 14 & $3-4$ & & X \\
\hline Bailey & M & $\begin{array}{l}20- \\
25\end{array}$ & Norwich, UK & Spain & 35 & 5.5 & X & \\
\hline
\end{tabular}

\section{Preliminary Findings}

This section will discuss the preliminary findings from our study. We found that some participants consider digital-free travel as a great opportunity for them to take a break from social and professional commitments. Heike described, that being completely disconnected from all commitments of which she would have been reminded of, if she would have used her phone, made it possible for her to switch to holiday mode right after she disconnected: "I got used to it very quickly that I did not have any Internet and it was really convenient. I felt like I was on holidays and far away from everything, really relaxed and I enjoyed it much more as I was completely disconnected and could switch off entirely. I did not think of my work at all, not until the second to last evening. I felt very free and relaxed". Frank disclosed that the refreshing and liberating feeling of digital-free travel came from 'not having to expose myself to the news (most of which is typically annoying political-related news) nor expose myself to work-related email messages that typically arrive on my phone'. After her digital-free travel experience, Anita wants to do more in the future: 'I'd love to go back to being able to disconnect from reality when on holiday and move away from the expectation from others to always be available'. Although Anita liked her digital-free travel, she found that IES from her colleagues (they expect her to be connected) makes it very difficult to leave her professional commitments behind and truly enjoy her holidays: 'the differences would come down to having to think about work because you are connected and people are trying to reach you'.

We found that IES coming from travelers' commitments in their daily lives are one of the key forces that create negative disconnecting emotions and prevent them from fully engaging with digital-free tourism. Travelers still practice their obligations and social roles as employees, family members, and partners mediated by technology. Although, they judge the idea of going digital-free as appealing, they cannot, and often do not want to let go of their professional and private commitments and therefore, do not fully disconnect. Due to their various responsibilities at work and at home that come with their different roles, they feel obligated to be available and responsive as they did not want to fail their colleagues, friends and family members that were seeking information from them, needed their help or just wanted to know if they are OK.

Many of our participants have too many personal and professional commitments which hardly allow them to be disconnected and unavailable for a certain amount of time. Nico noted that due to the nature of his job, he could hardly dare to switch off and hand over the responsibility to his employees: 'to be honest, two days before the trip I was a little bit nervous about it, because I knew the guys I am working with, I was leaving them with a lot of responsibility of stuff in an area where they were not aware of everything, where they did not understand everything. So, I was quite nervous about it. So, to a certain degree, two days before the trip I was like do I really wanna do this? Is that really a good time?'. Doug explained that the digital-free holiday almost led to him missing an important opportunity at work as he did not respond to an email he received during his digital-free travel: I got an important 
email on the Friday that I did not respond until Monday, which could have been a missed opportunity because there was a deadline on it'.

Not only professional commitments, but also personal commitments have significant effects. Andy was expecting an important parcel and was nervous that he couldn't track it and did not know if it arrives on time: 'I did have a nagging feeling to check my messages and emails to see whether a delivery had arrived back at home in Melbourne or not. I later found out that it did arrive on time, but this was the following day when I had regained my access to technology' (Billy). Rory has a pet rabbit and found it is impossible to disconnect on holiday. In the past, her rabbit has stopped eating and needed to be taken to the vet. During her trip away she tried to be disconnected but could not fully switch off the whole time as she wanted to check with her flatmate if her pet was still eating properly: 'in my case, I wasn't fully disconnected because I have a rabbit. Sometimes if my rabbit stopped eating, it will die...I wanted my flatmate to be able to contact me in case something went wrong'.

Houjia stated that her mother won't allow her to disconnect when she travels alone: 'she will be worried about what if I am in danger, and she cannot reach out to me'. She admitted that she experienced pressure from her mum to be always available when she is travelling: 'it creates this kind of anxiety. Even though I have my phone, but I do not have reception, it will create certain kind of anxiety to me'. Similarly, Frank also noted the feeling of being obligated to report whereabouts on holiday under social surveillance. He also wanted to check what his friends and family are doing and therefore, wanted to check his messages and social media 'I did not *HAVE* to use technology, but I felt I needed to catch up on text messages and social media to see what had been going on with my family/friends during that day'. This shows the reciprocity of social surveillance. Not only do our travelers feel that they are obligated to be available and responsive, but they also want to be updated about any private and work-related matters.

The norm of ubiquitous connectivity and social surveillance results in people feeling that they need to be available and responsive even during their planned digital-free holidays. Based on their past connectivity patterns, people expect travelers to post on social media and to respond to messages or emails within their usual times. James who is usually very responsive and posts frequently on social media worried about the emails he had in his inbox that are waiting for him and that someone tried to contact him however, couldn't get hold of him: 'It has been almost 24 hours without technology and I am starting to wonder how many emails do I have, or Facebook posts. As I had posted on Facebook before I disconnected that I was going to Vienna. I'm also slightly worried someone might be trying to contact me, and getting worried I am not replying. I did tell the people for that matter I was disconnecting but I'm still worried. What if something bad has happened and they can't get hold of me'? (James). On another digital-free trip, James perceived similar feelings, but he realized that he did not get as many emails and messages as he thought he would get. He concluded that it is OK to disconnect, and that people do not contact him as often as he thought. 'I spent the day wondering if people had tried to contact me. But when we got home and got my phone back there was no messages on Facebook, text message or anything. It made me think how much do I really need my phone during the day'.

Frank experienced anxiety and stress-inducing feelings as he did not tell many people that he was on a digital-free holiday. He worried about the fact that people might try to reach out to him, but cannot: 'I hadn't mentioned to anyone outside of my travel friends that I was going without technology that day so I was worried that they might have been wondering why I had disappeared and been non-responsive that day'. Known as being always available and responsive online, Doug felt it is important to 
manage people's expectations and let them know that he will be disconnected for a certain time: 'letting people know that you're going to have limited connectivity. Probably the longest that I could go without any communication would be two weeks and that would require letting a lot of people know'.

\section{Conclusion and Implications}

In this research in progress paper, we presented our preliminary findings on the impact of social and professional commitments mediated by interpersonal electronic surveillance on the decisions and experiences of travelers that go on a digital-free holiday. Based on our data analysis we found that travelers that choose to go on a digital-free holiday need to deal with the stress and anxieties of disconnecting from collective expectations deriving from their social and professional commitments. Due to many commitments, some participants found it challenging; some even decided to reconnect earlier and return to the status of copresence. Our next steps are to more thoroughly theoretically analyze the data using the surveillance lens.

By understanding how social and professional commitments prevent travelers from engaging in the digital-free travel experience, this study not only contributes to the emerging digital-free tourism literature, but also provides new insights into the notion of copresence by investigating the paradox between autonomy and interpersonal surveillance in a disconnected context. The findings can also provide insights to tour operators and hospitality providers who are designing digital-free related products.

\section{References}

1. Neuhofer, B., D. Buhalis, and A. Ladkin, A typology of technology-enhanced tourism experiences. International Journal of Tourism Research, 2014. 16(4): p. 340-350.

2. Dery, K., D. Kolb, and J. MacCormick, Working with connective flow: how smartphone use is evolving in practice. European Journal of Information Systems, 2014. 23(5): p. 558-570.

3. Ayeh, J.K., Distracted gaze: Problematic use of mobile technologies in vacation contexts. Tourism Management Perspectives, 2018. 26: p. 31-38.

4. Mazmanian, M., W.J. Orlikowski, and J. Yates, The autonomy paradox: The implications of mobile email devices for knowledge professionals. Organization science, 2013. 24(5): p. 1337-1357.

5. Mazmanian, M., Avoiding the trap of constant connectivity: When congruent frames allow for heterogeneous practices. Academy of Management Journal, 2013. 56(5): p. 1225-1250.

6. Cai, W., B. McKenna, and L. Waizenegger, Turning it off: Emotions in digitalfree travel. Journal of Travel Research, 2019: p. in press.

7. Tokunaga, R.S., Social networking site or social surveillance site? Understanding the use of interpersonal electronic surveillance in romantic relationships. Computers in Human Behavior, 2011. 27(2): p. 705-713.

8. Hermida, A. and V. Hernández-Santaolalla, Horizontal surveillance, mobile communication and social networking sites. The lack of privacy in young people's daily lives. Communication \& Society, 2020. 33(1): p. 139-152.

9. Marwick, A., The public domain: Surveillance in everyday life. Surveillance \& Society, 2012. 9(4): p. 378-393.

10. Kaplan, C., Transporting the subject: technologies of mobility and location in an era of globalization, in Transactions and Proceedings of the Modern Language Association of America. 2002. p. 32-42.

11. Green, N., Who's watching whom? Monitoring and accountability in mobile relations, in Wireless world. 2002, Springer. p. 32-45.

12. Wajcman, J. and E. Rose, Constant connectivity: Rethinking interruptions at work. Organization studies, 2011. 32(7): p. 941-961. 
13. Floros, C., et al., Imagine being off-the-grid: millennials' perceptions of digitalfree travel. Journal of Sustainable Tourism, 2019. In press: p. 1-16.

14. Urry, J.J.S., Mobility and proximity. 2002. 36(2): p. 255-274.

15. Gergen, K.J.J.P.c.M.c., private talk, public performance, 14 The challenge of absent presence. 2002: p. 227.

16. Hannam, K., G. Butler, and C.M. Paris, Developments and key issues in tourism mobilities. Annals of Tourism Research, 2014. 44: p. 171-185.

17. Zhao, S. Toward a Taxonomy of Virtual Presence. in Presence 2001: International Workshop. 2001.

18. White, N.R. and P.B. White, Home and away: Tourists in a connected world. Annals of Tourism Research, 2007. 34(1): p. 88-104.

19. Humphreys, L., Who's watching whom? A study of interactive technology and surveillance. Journal of Communication, 2011. 61(4): p. 575-595.

20. Trottier, D., A research agenda for social media surveillance. Fast Capitalism, 2011. 8(1): p. 59-68.

21. Germann Molz, J., 'Watch us wander': mobile surveillance and the surveillance of mobility. Environment and Planning A, 2006. 38(2): p. 377-393.

22. Germann Molz, J., 'Watch us wander': mobile surveillance and the surveillance of mobility. Environment Planning A, 2006. 38(2): p. 377-393.

23. Dickinson, J.E., J.F. Hibbert, and V. Filimonau, Mobile technology and the tourist experience: (Dis)connection at the campsite. Tourism Management, 2016. 57: p. 193-201.

24. Li, J., P.L. Pearce, and D. Low, Media representation of digital-free tourism: A critical discourse analysis. Tourism Management, 2018. 69: p. 317-329.

25. Cooper, G., The mutable mobile: social theory in the wireless world, in Wireless World: Social and Interactional Aspects of the Mobile Age, B. Brown, N. Green, and R. Harper, Editors. 2002, Springer: London. p. 17-31.

26. Paris, C.M., et al., Disconnected and unplugged: experiences of technology induced anxieties and tensions while traveling, in Information and Communication Technologies in Tourism 2015, I. Tussyadiah and A. Inversini, Editors. 2015, Springer: London. p. 803-816.

27. O'Regan, M., Hypermobility in backpacker lifestyles: The emergence of the internet café. Tourism mobilities: Local-global connections, 2008: p. 109-132.

28. Tanti, A. and D. Buhalis, Connectivity and the consequences of being (dis) connected, in Information and communication technologies in tourism 2016. 2016, Springer. p. 31-44.

29. Germann Molz, J. and C.M. Paris, The Social Affordances of Flashpacking: Exploring the Mobility Nexus of Travel and Communication. Mobilities, 2015. 10(2): p. 173-192.

30. Neuhofer, B. and A. Ladkin, (Dis) connectivity in the travel context: Setting an agenda for research, in Information and communication technologies in tourism 2017. 2017, Springer. p. 347-359.

31. Pearce, P.L. and U. Gretzel, Tourism in technology dead zones: Documenting experiential dimensions. International Journal of Tourism Sciences, 2012. 12(2): p. 1-20.

32. Rosenberg, H., The "flashpacker" and the "unplugger": Cell phone (dis) connection and the backpacking experience. Communication Mobile Media, 2019. 7(1): p. 111-130.

33. Tribe, J. and M. Mkono, Not such smart tourism? The concept of e-lienation. Annals of Tourism Research, 2017. 66: p. 105-115.

34. Wengraf, T., Qualitative research interviewing: Biographic narrative and semistructured methods. 2001, London: Sage.

35. Walsham, G., Doing interpretive research. European Journal of Information Systems, 2006. 15(3): p. 320-330.

36. Vu, H.Q., et al., Tourist activity analysis by leveraging mobile social media data. Journal of travel research, 2018. 57(7): p. 883-898.

37. Braun, V. and V. Clarke, Using thematic analysis in psychology. Qualitative research in psychology, 2006. 3(2): p. 77-101. 